\title{
TUGAS DAN WEWENANG PUSAT PELAPORAN DAN ANALISIS TRANSAKSI KEUANGAN (PPATK) DALAM PEMBERANTASAN TINDAK PIDANA PENCUCIAN UANG
}

\author{
Johari
}

Dosen Fakultas Hukum Universitas Malikussaleh Aceh

\begin{abstract}
Abstrak
Tugas dan wewenang Pusat Pelaporan dan Analisis Transaksi Keuangan (PPATK) terdapat di dalam Pasal 26 dan Pasal 27 Undang-Undang No. 25 Tahun 2003 tentang Tindak Pencucian Uang. Berdasarkan ketentuan tersebut, tugas dan wewenang PPATK tersebut bertujuan untuk mendeteksi terjadinya tindak pidana pencucian uang, dan membantu penegakan hukum yang berkaitan dengan pencucian uang, termasuk tindak pidana asal yang melahirkannya (predicate offences). Namun, Peranan PPATK akan berjalan secara efektif apabila aparat penegak hukum seperti Kepolisian, Kejaksaan, Pengadilan, Bea dan Cukai, para regulator seperti Bank Indonesia, Departemen Keuangan, Badan Pengawas Pasar Modal serta Penyedia Jasa Keuangan, industri perbankan, asuransi, perusahaan pembiayaan, dana pensiun, perusahaan efek, pengelola reksadana, media massa, masyarakat bekerjasama secara terorganisir dan terpadu dalam pemberantasan tindak pencucian uang di Indonesia. Dengan kewenangan yang dimilikinya, PPATK dapat mengejar hasil dari kejahatan, apabila hasil kejahatan tersebut dapat dikejar dan disita maka negara dengan sendirinya akan mengurangi tindak kejahatan itu sendiri.
\end{abstract}

Kata kunci : Pencucian uang, tindak pidana pencucian uang (money laundering), kejahatan terorganisir, dan Pusat Pelaporan dan Analisis Transaksi Keuangan (PPATK).

\section{PENDAHULUAN}

Kegiatan pencucian uang bukan merupakan kejahatan baru. Kejahatan ini pertama kali muncul di negara maju sebagai akibat daripada perkembangan perdagangan obat bius. Kejahatan terorganisir seperti pencucian uang tidak hanya didasarkan kepada jumlah pelaku. Pencucian uang dilakukan tidak saja secara terorganisir berdasarkan jumlah pelaku akan tetapi sistematis yang dapat melintasi batas yurisdiksi negara. Kejahatan terorganisir dibentuk berdasarkan sistematika kerja yang tersusun secara rapi.
Jaringan tidak harus bersifat permanen akan tetapi daya kerja harus dinamis.

Antara model, modus operandi, metode serta instrumen disesuaikan sehingga dapat berlaku efektif. Unsur model tidak bersifat mutlak, tanpa model kegiatan pencucian uang tidak dapat terlaksana. Kejahatan teroganisir selalu didukung oleh perkembangan teknologi serta berpeluang pada cyber space sehingga kejahatan terorganisir disebut cyber crime termasuk pencucian uang.

Tindak pidana pencucian uang banyak dilakukan dengan 
menggunakan media atau jasa dari institusi-institusi keuangan. Berdasarkan Surat Keputusan Kepala Pusat Pelaporan dan Analisis Transaksi Keuangan (PPATK) No 2/1/KEP.PPATK/2003 bahwa Penyedia Jasa Keuangan (PJK) atau lembaga-lebaga keuangan terdiri dari Perbankan, Lembaga keuangan non bank, dan Perusahaan efek, pengelola reksa dana dan Bank Kustodian.

Namun, dari sekian banyak lembaga keuangan maka pasar modal

1 Menurut penjelasan umum UndangUndang No. 15 tahun 2002 tentang Pencucian Uang, penyedia jasa keuangan diartikan sebagai penyedia jasa dibidang keuangan termasuk tetapi tidak ter-batas kepada bank, lembaga pembiayaan, perusahaan efek, pengelola reksa dana,kustodian, wali amanat, lembaga penyimpanan dan penyelesaian, pedagang valuta asing, dana pensiun dan perusahaan asuransi. Efek, kustodian, lembaga penyimpanan dan penyelesaian, perusahaan efek, pengelola reksa dana, rekening efek, reksa dana, dan wali amanat adalah efek, kustodian, lembaga penyimpanan dan penyelesaian, perusahaan efek, pengelola reksa dana, rekening efek, reksa dana, wali amanat sebagaimana dimaksud dalam peraturan perundang-undangan yang mengatur mengenai pasar modal. Konsideran Undang-Undang No. 8 tahun 1995 tentang Pasar Modal menyebutkan bahwa, pasar modal mempunyai peran yang strategis dalam pembangunan nasional sebagai salah satu sumber pembiayaan bagi dunia usaha dan wahana investasi bagi masyarakat. Selain itu pasar modal untuk lebih menjamin kepastian hukum pihakpihak yang melakukan kegiatan pasar modal serta melindungi kepentingan masyarakat pemodal dan praktik yang merugikan. Konsideran Undang-Undang No. 7 tahun 1972 tentang Perbankan menyebutkan bahwa sebagai penyalur dan penghimpun dana masyarakat memiliki peranan yang strategis untuk menunjang pelaksanaan pembangunan nasional dalam rangka meningkatkan pemerataan pembangunan dan hasil-hasilnya, pertumbuhan ekonomi dan stabilitas nasional kearah peningkatan hidup rakyat banyak. dan perbankan merupakan lembaga penyedia jasa keuangan yang paling mudah dan aman melakukan kegiatan pencucian uang, karena nilai tukar mata uang, harga indeks saham setiap saat dapat diketahui melalui kegiatan pasar modal yang di dalamnya terdapat bursa efek dan perusahaan efek. Sedangkan penyimpanan uang atau surat berharga lainnya dan kisaran suku bunga bank diketahui melalui peraturan perbankan.

Kedua lembaga penyedia jasa keuangan ini mengelola perdagangan saham, nilai tukar mata uang dan suku bunga bank berdasarkan peranannya masing-masing. Uang masuk dan keluar secara bebas melalui lembaga penyedia jasa keuangan tersebut dan akan menunjukan bahwa semua transaksi secara legal. Timbul pertanyaan apakah keluar masuknya uang secara legal ini memang legal menurut undang-undang (wetmatigheid), hukum (rechtmatigheid), tujuan tidak menyimpang (doel-matigheid) dan memenuhi syarat secara administratif (administrative matigheid).

Apabila ke empat unsur ini secara impratif tidak terpenuhi maka ada indikasi terjadi pencucian uang. Kejahatan dibidang pasar modal adalah kejahatan yang khas dilakukan oleh pelaku pasar modal dalam kegiatan pasar modal. Secara nasional untuk mengatasi kejahatan pasar modal telah dikeluarkan Undang-Undang No. 8 tahun 1995 yang menentukan bahwa kejahatan pasar modal dapat terjadi karena adanya kesalahan pelaku, ${ }^{2}$ kelemahan aparatur pemerintah yang mencakup integritas dan

2 M. Irsan Nasarudin dan Indera Surya, Aspek Hukum Pasar Modal Indonesia, Prenada Media, Jakarta, 2004, hlm. 258. 
profesionalisme dan kelemahan peraturan.

Padahal lembaga pasar modal merupakan lembaga kepercayaan, yaitu sebagai lembaga perantara (intermediary) yang menghubungkan antara kepentingan pemakai dana (issuwer, ultimate borrower), dan para pemilik dana pemodal, (ultimate lender). Lembaga kepercayaan ini penelitian aspek hukum, yaitu perangkat perundang-undangan yang mengatur pasar modal akan memberikan kontribusi positif bagi penegakan hukum untuk memberikan jaminan dan kepastian hukum kepada pelaku pasar modal. ${ }^{3}$

Perkembangan saat ini menunjukkan bahwa jumlah kejahatan pencucian uang setiap tahunnya meningkat. Hal ini dapat dilihat dari data yang dikeluarkan Pusat Pelaporan dan Analisis Transaksi Keuangan (PPATK) menunjukkan bahwa pada tahun 2007 sampai dengan tahun 2003 jumlah kasus pencuian uang berdasarkan Laporan Transaksi Keuangan Mencurigakan (LTKM) sebanyak 524 kasus. ${ }^{4}$ Sedangkan pada tahun 2008 berdasarkan LTKM

3 Ibid, hlm. 259.

${ }^{4}$ Berdasarkan hasil analisis dari 31 Laporan Transaksi Keuangan Mencurigakan (LTKM). bahwa pada tahun 2003 kasus tindak pidana pencucian uang berjumlah 24 kasus. Sedangkan pada tahun 2004 kasus tindak pidana pencucian uang semakin meningkat yaitu berjumlah 212 kasus berdasarkan analisis dari 314 (LTKM). Tahun 2005 berjumlah 111 kasus dari 144 LTKM. Tahun 2006 berjumlah 86 kasus dari 144 LTKM. Tahun 2007 berjumlah 91 kasus dari 376 LTKM. Laporan Tahunan Pusat Pelaporan dan Analisis Transaksi Keuangan tahun 2007, http://www.ppatk.go.id/ laporan_tahunan. php diakses 1 Pebruari 2010. jumlah kasus pencucian uang terdapat 869 kasus. $^{5}$

Kasus tindak pidana pencucian uang ternyata bukan hanya terjadi di tingkat pusat saja tetapi juga terjadi di tingkat daerah. Hal ini diakibatkan dengan meningkatnya jumlah kejahatan yang mendukung atau menjadi sumber kejahatan pencucian uang. Hampir disemua wilayah di Indonesia kejahatan korupsi, pengemplang pajak, perjudian, prostitusi dan illegal longging ada dan jumlahnya semakin meningkat setiap tahunnya. Sehingga jenis-jenis kejahatan inilah yang menjadi sumber terjadinya kejahatan pencucian uang. Modus operandi yang dilakukan sangat sistematis dan terorganisir. Oleh karena itu, negara harus menyadari bahwa ini adalah sebuah ancaman yang besar terhadap perekonomian bangsa, apabila ini tidak ditindak secara terstruktur dan sistematis maka pertumbuhan dan stabilitas ekonomi nasional akan terganggu.

Pemberantasan tindak pidana pencucian uang akan lebih efektif apabila aparat penegak hukum seperti Kepolisian, Kejaksaan, Pengadilan, Bea dan Cukai, para regulator seperti Bank Indonesia, Departemen Keuangan, Badan Pengawas Pasar Modal serta Penyedia Jasa Keuangan, industri perbankan, asuransi, perusahaan pembiayaan, dana pensiun, perusahaan efek, pengelola reksadana, media massa dan masyarakat bekerjasama dan memberikan kontribusi yang positif terhadap pemberantasan pencucian uang di Indonesia.

\footnotetext{
5 http:// www. suaramedia.com/ekonomibisnis/ekonomi/6474-kasus-pencucian-uangterus-meningkat.html, diakses 1 Pebruari 2010.
} 
Undang-Undang No. 15 Tahun 2002 Tentang Tindak Pencucian Uang sebagaimana telah diubah dengan Undang-Undang No. 25 Tahun 2003 mengamanatkan keberadaan PPATK sebagai lembaga sentral dalam pelaksana dari undangundang yang di undangkan sejak tanggal 17 April 2002 tersebut. Hanya saja sukses atau tidaknya pemberantasan tindak pidana pencucian uang di Indonesia, tidak tergantung semata-semata kepada PPATK tetapi semua peranan dari berbagai elemen bangsa Indonesia.

Berdasarkan uraian tersebut, tulisan ini bermaksud menganalisis pengertian pencucian uang sebagai tindak pidana, dasar hukum tindak pidana pencucian uang, menelusuri keberadaan pencucian uang sebagai kejahatan terorganisir, serta tugas dan wewenang Pusat Pelaporan dan Analisis Transaksi Keuangan (PPATK) dalam pemberantasan tindak pidana pencucian uang (money laundering).

\section{PEMBAHASAN}

\subsection{Pengertian Pencucian Uang}

Istilah money laundering dalam bahasa Indonesia adalah pemutihan uang atau pencucian uang. Hal ini adalah terjemahan yang wajar, karena kata launder dalam bahasa inggris adalah mencuci. Oleh karena itu, sehari-hari dikenal kata laundry yang berarti cucian. Uang yang diputihkan atau dicuci adalah uang dari hasil kejahatan, misalnya uang dari hasil korupsi, jual beli narkoba, perjudian, prostitusi dan sebagainya. ${ }^{6}$

6 Munir Fuady, Bisnis Kotor (anatomi Kejahatan Kerah Putih), Citra Aditya Bakti, Bandung, 2004, hlm. 83.
Menurut Mahmoeddin As, dalam sejarah hukum bisnis munculnya money laundering dimulai dari negara Amerika Serikat sejak Tahun 1830. Pada waktu itu banyak orang yang membeli perusahaan dengan uang hasil kejahatan, seperti hasil perjudian, penjualan narkotika, minuman keras secara illegal dan hasil pelacuran. Hal ini dilakukan oleh organisasiorganisasi ganster di Amerika. Pusatpusat gangster besar yang piawai masalah pencucian uang di Amerika Serikat yang terkenal dengan nama kelompok legendaries Al Capone (Chicago). ${ }^{7}$

Menurut Welling, money laundering adalah:

Money laundering is the process by which one counceals the existence, illegal source or illegal application of income and than disguises that income to make it appear legitimate. ${ }^{8}$

Berdasarkan Black's Law Dictionary, money laundering adalah:

Term used to describe investment or orther transfer of money flowing from racekteering, drug transactions and either illegal sorces into legitimate channels so that its

\footnotetext{
7 Munir Fuady, Hukum Perbankan Indonesia, Cirtra Aditya Bakti, Bandung, 2001, hlm. 154.

8 Sarah N. Welling, Smurfd, Money Laundring and the United Atate Criminal Federal Law. Dalam Brent Fisse, David Fraser and Graeme Coss, The Money Trail (Confiscation of proceed of Crime. Money Laundering and Cash Transaction Reporting), Sydney, The Law Book Company Limited, 1992, hlm.201.
} 
original source can not be traced..$^{9}$

Mayer Lansky memutihkan atau mencuci uang kotor milik kelompok $A l$ Capone dengan mengembangkan pusat perjudian, pelacuran, serta bisnis hiburan malam di Las Vegas (Nevada). Lalu dikembangkan lagi offshore banking di Havana (Cuba) dan Bahama. Kegiatan pencucian uang yang dilakukan oleh kelompok ini menjadikan Mayer Lansky dijuluki sebagai bapak Money Laundering Modern. Setelah memasuki tahun 1980 an kegiatan ini semakin menjadi-jadi dengan banyaknya penjualan obat bius di wilayah tersebut. $^{10}$

Bertolak dari rentang waktu perjalanan tindak pidana pencucian uang, maka dikenallah istilah narco dollar atau drug money yang merupakan uang hasil penjualan narkotika. Perkembangan selanjutnya, uang dari hasil kejahatan itu disimpan di lembaga keuangan antaranya di bank. Penyimpanan uang hasil kejahatan ini dengan tujuan agar uang hasil dari kejahatan itu menjadi legal. Bahkan, dunia internasional telah bersepakat melarang kejahatan yang berhubungan dengan narkotika dan pencucian uang.

Kesepakatan ini dituangkan dalam sebuah konvensi the United Nation Convention Against Illicit Trafic in Narcotics, Drugs and Pasalycotropic Substances of 1988, yang biasa disebut dengan the Vienna Convention, disebut juga United Nation Drug Convention 1988 yang mewajibkan para

9 Henry Campbell Black, Black's Law Dictionary, Sixth Edition, St. Paul Minn, West Publishing Co, 1991, hlm. 611.

${ }^{10}$ Ibid. anggotanya untuk menyatakan pidana terhadap pelaku tindakan tertentu yang berhubungan dengan narkotika dan money laundering.

Apabila uang hasil kejahatan dipergunakan dan atau dimasukkan ke dalam dunia peredaran uang termasuk lembaga keuangan, berarti status uang itu identik dengan uang yang diperoleh dari kegiatan yang legal. Jika demikian berarti akan menumbuh suburkan kejahatan yang bermotif uang baik kejahatan konvensional maupun moderen, sehingga samar perbuatan yang legal dan illegal. Pencucian uang tidak dilakukan seperti kejahatan tradisional lainnya walaupun bentuk kejahatannya sama seperti penipuan atau penyuapan.

Apakah sama cara melakukan kedua tindak pidana ini dari waktu ke waktu atau dari situasi ke situasi berlainan atau oleh orang yang satu dengan orang yang lain atau dapat terjadi pelakunya sama, akan tetapi objek dan korbannya tidak sama. Kejahatan ini berkembang seiring perkembangan Ilmu Pengetahuan dan Teknologi (IPTEK). Kegiatan pencucian uang akan menyesuaikan diri dengan perkembangan IPTEK. Penipuan, penyuapan secara tradisional akan langsung dilakukan dengan tunai. Akan tetapi penyuapan dan kegiatan penipuan dilakukan dengan kecanggihan teknologi tidak harus pada suatu tempat tertentu.

Praktik money laundering bisa dilakukan oleh seseorang tanpa harus berpergian ke luar negeri. Sifat money laundering menjadi universal dan bersifat internasional yakni melintasi batas-batas yurisdiksi negara. ${ }^{11}$ Berarti Money laundering

11 NHT. Siahaan, Pencucian Uang dan Kejahatan Perbankan, Sinar Harapan, Jakarta, 2005, hlm. 103. 
berhubungan dan dicapai dengan kemajuan teknologi melalui system cyberspace (internet), pembayaran dilakukan melalui bank secara elektronik (cyberpayment). ${ }^{12}$

Sudarmadji salah seorang penasehat hukum Bank Indonesia menyebutkan bahwa tindak pidana penyuapan, korupsi, perjudian, pemalsuan uang merupakan pemicu money laundering. ${ }^{13}$

Money Laundering dapat menimbulkan ketidak percayaan nasabah dan masyarakat kepada sistem perbankan. Apabila dikatakan bahwa kegiatan pencucian uang telah menembus batas negara berarti pemahaman hukum pidana terhadap kejahatan ini tidak lagi terkait dengan azas teritorial suatu negara saja akan tetapi lebih dari satu hukum nasional yang dilanggar. Uang hasil dari tindak pidana ini tidak saja disimpan atau dimanfaatkan dalam suatu lembaga keuangan suatu negara, akan tepi juga dapat ditransfer ke negara lain dengan berbagai macam cara dan kepentingan.

Ada kepentingan untuk membiayai kegiatan teroris dan ada juga untuk proses bisnis. Kegiatan semacam ini melibatkan lebih dari satu hukum pidana nasional. Kasuskasus kejahatan money laundering seperti mantan Presiden Phillipina Ferdinand Marcos, uang hasil tindak pidana korupsinya disimpan di Bank Credit Swiss. ${ }^{14}$

${ }^{12}$ Ibid. hlm. 3.

13 Sudarmadji. Essensi dan Cakupan UU Tentang Pencucian Uang di Indonesia, Makalah Seminar Nasional pada Sosialisasi Undang-Undang No. 15 Tahun 2002, Kerjasama Kajian Hukum dan Bisnis Fakultas Hukum Unsri dengan PT. Bank Pembangunan Daerah Sumatera Selatan pada 15 Juli 2002, hlm. 12.

${ }^{14}$ Munir Fuady, 2001, Op.Cit, hlm. 186-195.
Begitu juga dengan mantan Presiden negara Panama yaitu Noriega. Noriega melakukan perdagangan obat bius dan uangnya disimpan di Amerika dan akhirnya dia di penjarakan di Amerika. Kegiatan money laundering oleh bank seperti kasus Bank Bank of Credit \& Commerce Internasional (BCCI) Tahun 1991.

Salah satu kasus BCCI adalah dibukanya rekening di BCCI oleh sebuah kantor konsultan keuangan yang mengatakan mempunyai klien berupa investor kaya di negara Amerika Latin. Jenis-jenis kejahatan money laundering yang dilakukan BCCI berhubungan dengan perdagangan obat bius. BCCI bertindak sebagai penyalur uang hasil transaksi itu. Kemudian Tahun 1990 Dinas Bea dan Cukai Amerika Serikat berhasil membongkar jaringan perdagangan obat bius yang melibatkan BCCI. Kasus Chemical Bank Tahun 1977.

Chemical Bank cabang New York melalui salah seorang manajernya menerima suap dari seorang yang terlibat dalam perdagangan obat bius agar transaskinya berupa setoran uang (hasil kejahatan) dalam rekening valas tersebut tidak dilaporkan dengan tidak mengisi formulir Currency Transaction Report (CTR). Jika diperhatikan uang hasil money laundering itu telah melalui dua periode. Pertama, uang itu diperoleh dari kejahatan, kedua uang itu dibersihkan melalui money laundering dengan berbagai cara sehingga menjadikan uang itu legal.

\subsection{Dasar Hukum Tindak Pidana Pencucian Uang}

Berdasarkan Undang-Undang No. 7 Tahun 1997, Negara Indonesia 
telah meratifikasi the United Nation Convention Against Illicit Trafic in Narcotics, Drugs and Pasalycotropic Substances of 1988, yang biasa disebut dengan the Vienna Convention, atau disebut juga United Nation Drug Convention 1988. Dalam konvensi tersebut bahwa adanya pelarangan dan penindakan yang tegas terhadap pelaku tindak pidana pencucian uang dan obat-obat terlarang. Implementasi daripada ratifikasi tersebut baru mulai efekti pada Tahun 2002 dengan menerbitkan sebuah undang-undang yaitu Undang-Undang No 15 Tahun 2002 yang menentukan bahwa money laundering sebagai suatu tindak pidana. Undang-Undang No 15 Tahun 2002 kemudian diubah dengan Undang-Undang No 25 Tahun 2003. Konsideran UndangUndang No 15 Tahun 2002 jelas menyatakan bahwa pencucian uang bukan saja merupakan kejahatan nasional tetapi juga kejahatan transnasional, oleh karena itu harus diberantas, antara lain dengan cara melakukan kerja sama regional atau internasional melalui forum bilateral atau multilateral.

Konsideran Undang-Undang No. 25 Tahun 2003 menyatakan bahwa agar upaya pencegahan dan pemberantasan tindak pidana pencucian uang dapat berjalan secara efektif, maka Undang-Undang No. 15 Tahun 2002 perlu disesuaikan dengan perkembangan hukum pidana tentang pencucian uang dan standar internasional. Kriminalisasi tindak pidana berpedoman kepada sifat hukum pidana, yaitu clarity (jelas), certainty (pasti), proportion (terukur), speedy (cepat) dan prevention (bersifat mencegah). Kriminalisasi pencucian uang terdapat dalam Pasal 3 UndangUndang No. 25 Tahun 2003.

Rumusan Pasal 3 paralel dengan rumusan Pasal 1 angka 1. Pencucian uang adalah perbuatan menempatkan, mentransfer, membayarkan, membelanjakan, menghibahkan, menyumbangkan, menitipkan, membawa ke luar negeri, menukarkan, atau perbuatan lainnya atas harta kekayaan yang diketahuinya atau patut diduga merupakan hasil tindak pidana dengan maksud untuk menyembunyikan, atau menyamarkan asal usul harta kekayaan sehingga seolah-olah menjadi harta kekayaan yang sah.

\subsection{Pencucian Uang sebagai Kejahatan Terorganisir}

Mendeskripsikan pencucian uang sebagai kejahatan terorganisir (Organized Crime) dilihat dari segi kriminalisasi dan pelaku. Kriminalisasi suatu tindak pidana merupakan bagian dari proses penegakan hukum pidana. Penegakan hukum Pidana melalui tiga tahap ${ }^{15}$ diantaranya tahap formulasi. Tahap ini disebut dengan tahap kebijakan legislatif. ${ }^{16}$

Pada tahap inilah terjadi proses kriminalisasi. Pada proses kriminalisasi tidak saja hanya merumuskan tindak pidana beserta sanksinya saja, akan tetapi menentukan atau memberikan sifat

\footnotetext{
${ }^{15}$ Muladi. Kapita Selekta Sistem Peradilan Pidana, Universitas Diponogoro, Semarang, 1995, hlm. 13.

16 Pada tingkat internasional usaha penegakkan hukum pidana tahap formulasi atau kriminalisasi dituangkan dalam bentuk konvensi. Konvensi mewajibkan negaranegara peserta membentuk undang-undang untuk memberantas kejahatan yang disebutkan dalam konvensi.
} 
apakah tindak pidana ini tindak pidana konvensional atau transnasional. Jika tindak pidana itu bersifat transnasional menunjukkan indikasi bahwa tindak pidana itu melampaui batas negara dan tidak terikat dengan yurisdiksi hukum satu negara saja. Semua negara (lebih dari satu) negara yang mengatur tindakan itu merupakan tindak pidana. Demikian juga kegitan dan pelaku, tentunya pelaku tidak terlepas dari perkembangan ilmu pengetahuan dan teknologi.

Pencucian uang sebagai tindak pidana yang terorganisir tentu ada beberapa pihak yang terlibat dan mempunyai tugas masing-masing. Biasanya organisasi seperti ini disebut dengan sindikat atau jaringan. Agar organisasi ini berjalan dengan sempurna sesuai dengan rencana perlu adanya kerangka tertentu sebagai sarana. Beberapa literatur yang membahas pencucian uang mengemukakan bahwa kegiatan pencucian uang mempunyai kerangka, model, modus operandi, instrumen, metode, tahapan serta pelaku tertentu dalam kegiatan kejahatan merupakan satu paket. Masing-masing sarana terdiri dari berbagai jenis sebagai alternatif.

Sarana-sarana ini menjadi pedoman melakukan pencucian uang sehingga untuk melakukan pencucian uang dapat dipilih dari beberapa alternatif sebagai berikut:

\section{Model Schaap}

Menurut Munir Fuady, banyak model untuk melakukan kejahatan pencucian uang. Diantara model pencucian uang yang paling lazim adalah :

a. Model dengan operasi C-Chase. Model ini menyimpan uang di bank dibawah ketentuan sehingga bebas dari kewajiban lapor transaksi keuangan (Non Currency Transaction Reports) dan melibatkan bank luar negeri dengan memanfaatkan tax haven.

b. Model pizza connection. Model ini memanfaatkan sisa uang yang ditanam di bank untuk mendapatkan konsesi Pizza, dan melibatkan negara tax haven dengan memanfaatkan ekspor fiktif.

c. Model La Mina. Model ini memanfaatkan pedagang grosir emas dan permata dalam negeri dan luar negeri.

d. Model dengan penyelundupan uang kontan ke negara lain. Model ini mem-pergunakan konspirasi bisnis semu dengan system bank parallel.

e. Model dengan melakukan perdagangan saham di Bursa Efek. Model ini melakukan kerja sama dengan lemabaga keuangan yang bergerak di bursa efek. ${ }^{17}$

\section{Modus Operandi}

Menurut Mahmoeddin yang dikutip oleh Munir Fuady mengemukakan ada delapan Modus Operandi, yaitu:

a. Kerjasama penanaman modal uang hasil kejahatan dibawa ke luar negeri. Kemudian uang itu dimasukkan lagi ke dalam negeri lewat proyek penanaman modal asing (joint venture). Selanjutnya keuntungan dari perusahaan joint venture diinvestasikan lagi ke dalam proyek-proyek yang lain, sehingga keuntungan dari proyek tersebut sudah uang bersih bahkan sudah dikenakan pajak.

b. Kredit Bank Swiss. Uang hasil kejahatan diselundupkan dulu ke

${ }^{17}$ Munir Fuady. Op.Cit, hlm. 198-206. 
luar negeri lalu dimasukkan di bank tertentu, lalu di transfer ke Bank Swiss dalam bentuk deposito. Deposito dijadikan jaminan hutang atas pinjaman di bank lain di negara lain. Uang dari pinjaman ditanamkan kembali ke negara asal dimana kejahatan dilakukan. Atas segala kegiatan ini menjadikan uang itu sudah bersih.

c. Transfer ke luar Negeri. Uang hasil kejahatan ditransfer ke luar negeri lewat cabang bank luar negeri di negara asal. Selanjutnya dari luar negeri uang dibawa kembali ke dalam negeri oleh orang tertentu seolah-olah uang itu berasal dari luar negeri.

d. Usaha tersamar di dalam negeri suatu perusahaan samaran di dalam negeri didirikan dengan uang hasil keja-hatan. Perusahaan itu berbisnis tidak mempersoalkan untung atau rugi. Akan tetapi seolah-olah terjadi adalah perusahaan itu telah menghasilkan uang bersih.

e. Tersamar dalam perjudian. Uang hasil kejahatan didirikanlah suatu usaha perjudian, sehingga uang itu dianggap sebagai usaha judi. Atau membeli nomor undian berhadiah dengan nomor menang dipesan dengan harga tinggi sehingga uang itu dianggap sebagai hasil menang undian.

f. Penyamaran dokumen. Uang hasil kejahatan tetap di dalam negeri, keberadaan uang itu didukung oleh dokumen bisnis yang dipalsukan atau direkayasa sehingga ada akibat bahwa uang itu merupakan hasil beberbisnis yang berhubungan dengan dokumen yang bersangkutan. Rekayasa itu misalnya dengan melakukan double invoice dalam hal ekspor impor sehingga uang itu dianggap hasil kegiatan ekspor-impor.

g. Pinjaman luar negeri. Uang hasil kejahatan dibawa ke luar negeri, kemudian uang itu dimasukkan lagi ke dalam negeri asal dalam bentuk pinjaman luar negri. Sehingga uang itu dianggap diperoleh dari pinjaman (bantuan kredit) dari luar negeri.

h. Rekayasa pinjaman luar negeri. Uang hasil kejahatan tetap berada di dalam negeri, namun dibuat rekayasa dokumen seakan-akan bantuan pinjaman dari luar negeri.

\section{Metode}

NHT Siahaan mengemukakan bahwa terdapat tiga metode yang dipergunakan melakukan pencucian uang, sebagai berikut:

a. Buy and Sell Conversions.

Metode ini dilakukan melalui transaksi barang dan jasa. Suatu aset dapat dijual kepada konspirator yang bersedia membeli atau menjual lebih mahal dengan mendapatkan fee atau diskon. Selisih harga yang dibayar kemudian dicuci secara transaksi bisnis. Barang atau jasa dapat diubah menjadi hasil yang legal melalui rekening pribadi atau perusahaan yang ada di suatu bank.

b. Offshore Conversions

Uang hasil kejahatan dikonversi ke dalam wilayah yang merupakan tempat yang sangat menyenagkan bagi penghindaran pajak (tax heaven money laundering centers) untuk kemudian di depositokan di bank yang berada di wilayah tersebut. Negara yang termasuk atau berciri tax heaven memang 
terdapat system hukum perpajakan yang tidak ketat. Akan tetapi system rahasia bank sangat ketat. Birokrasi bisnis cukup mudah untuk memungkinkan adanya ra-hasia bisnis yang ketat serta pembentukan usaha trust fund. Untuk mendu- kung usaha itu pelaku memakai jasa pengacara, akuntan dan konsultan keuangan dan para pengelola dana yang handal untuk memanfaatkan segala cela yang ada di negara itu.

c. Legitimate Business Conversions Metode ini dengan melakukan kegiatan bisnis yang sah sebagai cara peng-alihan atau pemanfaatan hasil uang kotor. Uang kotor kemudian dikonversi secara transfer, cek atau alat pembayaran lain untuk disimpan di rekening bank atau ditransfer kemudian ke rekening bank lainnya. Biasanya pelaku bekerja sama dengan perusahaan yang rekeningnya dapat digunakan sebagai terminal untuk menampung uang kotor. ${ }^{18}$

\section{Instrumen}

Instrumen yang dimaksud berupa lembaga penyedia jasa baik penyedia jasa keuangan berupa bank ataupun non bank maupun non keuangan. Ada delapan Instrumen yang dipergunakan dalam pencucian uang. yaitu:

a. Bank dan Lembaga Keuangan lainnya

b. Perusahaan Swasta

c. Real estate

d. Deposit Taking Institution dan Money Changer

e. Institusi Penanaman Uang Asing

${ }^{18}$ NHT.Siahaan, Op. Cit, hlm. 21. f. Pasar Modal dan Pasar uang.

g. Emas dan Barang Antik

h. Kantor konsultan keuangan. ${ }^{19}$

5. Tahapan

Tahapan dalam melakukan kejahatan pencucian uang adalah:

a. Placement adalah tahap ini upaya menempatkan uang tunai yang berasal dari tindak pidana ke dalam system keuangan (financial system) atau upaya menempatkan uang giral (cheque, wesel bank, sertifikat deposito, dan lain-lain) kembali ke dalam system keuangan, terutama system perbankan.

b. Layering adalah upaya untuk mentransfer harta kekayaan yang berasal dari tindak pidana (dirty money) yang telah berhasil ditempatkan pada penyedia jasa keuangan (terutama bank) sebagai hasil upaya penempatan (placement) ke penyedia jasa keuangan yang lain. Dengan dilakukan layering, akan menjadi sulit bagi pene-gak hukum untuk dapat mengetahui assal usul harta kekayaan tersebut.

c. Integration adalah upaya menggunakan harta kekayaan yang berasal dari tindak pidana yang te-lah berhasil masuk ke dalam system keuangan melalui penempatan atau trans-fer sehingga seolah-olah menjadi harta kekayaan halal (clean money) untuk kegiatan bisnis yang halal atau untuk membiayai kembali kegiatan kejahatan. ${ }^{20}$

\footnotetext{
19 M. Irsan Nasarudin dan Indera Surya. Aspek Hukum Pasar Modal Indonesia. Kencana, Jakarta, 2004, hlm. 19.

${ }^{20}$ Baca penjelasan umum Undang-Undang No. 25 Tahun 2003. Lembaran Negara No.
} 


\subsection{Tugas dan Wewenang Pusat Pelaporan dan Analisis Transaksi Keuangan (PPATK) dalam Pemberantasan Tindak Pidana Pencucian Uang (money laundering)}

Berdasarkan Pasal 26 dan Pasal 27 Undang-Undang No. 25 Tahun 2003 tentang Tindak Pidana Pencucian menentukan bahwa tugas PPATK antara lain mengumpulkan, menyimpan, menganalisis, menghimpun, mengevaluasi informasi yang diperoleh dari penyedia jasa keuangan, membuat pedoman mengenai tata cara pelaporan transaksi keuangan yang mencurigakan, memberikan nasihat dan bantuan kepada instansi lain yang berwenang, memberikan rekomendasi kepada Pemerintah sehubungan dengan pencegahan dan pemberantasan tindak pidana pencucian uang, melaporkan hasil analisis terhadap transaksi keuangan yang berindikasi tindak pidana pencucian uang kepada Kepolisian untuk kepentingan penyidikan dan Kejaksaan untuk kepentingan penuntutan dan pengawasan, membuat dan menyampaikan laporan mengenai analisis transaksi keuangan dan kegiatan lainnya secara berkala kepada Presiden, DPR dan lembaga yang berwenang melakukan pengawasan bagi Penyedia Jasa Keuangan (PJK).

Sedangkan kewenangan PPATK, antara lain meminta dan menerima laporan dari PJK, dan meminta informasi mengenai perkembangan penyidikan atau penuntutan terhadap tindak pidana pencucian uang yang telah

108 Tahun 2003 dan Tambahan Lembaran Negara No. 4324 Tahun 2003. dilaporkan kepada penyidik atau penuntut umum. Berdasarkan tugas dan wewenang tersebut di atas terdapat dua tugas utama yang menonjol dalam kaitannya dengan pemberantasan tindak pidana pencucian uang, yaitu tugas mendeteksi terjadinya tindak pidana pencucian uang dan tugas membantu penegakan hukum yang berkaitan dengan pencucian uang dan tindak pidana asalnya (predicate offences).

Dalam rangka mendeteksi tindak pidana pencucian uang, PPATK menerima laporan, yaitu :

a. Laporan transaksi keuangan mencurigakan yang disampaikan oleh penyedia jasa keuangan (Pasal 1 angka 6 dan Pasal 13 Undang-Undang No.25 Tahun 2003 Tentang Tindak Pencucian Uang),

b. Laporan yang disampaikan oleh penyedia jasa keuangan tentang transaksi keuangan yang dilakukan secara tunai dalam jumlah kumulatif Rp 500 juta atau lebih (pasal 13 UndangUndang No.25 Tahun 2003 Tentang Tindak Pencucian Uang).

c. Laporan yang disampakan oleh Direktorat Jenderal Bea Cukai mengenai pembawaan uang tunai rupiah ke dalam atau ke luar wilayah negara Republik Indonesia sejumlah Rp 100 juta atau lebih (Pasal 16 UndangUndang No.25 Tahun 2003 Tentang Tindak Pencucian Uang).

Berdasarkan Keputusan Presiden Republik Indonesia No. 82 Tahun 2003 Tentang Tata Cara Pelaksanaan Kewenangan Pusat Pelaporan dan Analisis Transaksi Keuangan juga dapat menerima informasi dari orang perseorangan 
mengenai dugaan tindak pidana pencucian uang. Laporan butir a dan c, terutama dimaksudkan untuk mendeteksi proses placement pada perbuatan pencucian uang, sementara laporan butir b terutama dimaksudkan untuk mendeteksi proses layering.

Atas dasar laporan tersebut dan informasi lainnya, PPATK melakukan analisa, (mendeteksi tindak pidana pencucian uang) kemudian menyerahkan laporannya kepada pihak Penyidik dan Penuntut (Pasal 27 Undang-Undang No.25 Tahun 2003 Tentang Tindak Pencucian Uang). Untuk memperoleh laporan dan hasil deteksi atau analisa yang baik PPATK menjalin kerjasama dengan PJK dan instansi terkait lainnya atau dengan Financial Intteligence Unit (FIU) dari negara lain.

Selanjutnya dalam proses penegakan hukum, PPATK dapat melakukan kerjasama dan membantu pihak penyidik dan penuntut umum dengan informasi yang dimiliki dan kemampuan analisisnya. Informasi tersebut dapat berasal dari data base PPATK atau dapat juga berasal dari sharing information dengan FIU dari negara lain. Dalam praktek saat ini berdasarkan kewenangan yang tertuang di dalam Keppres No. 82 Tahun 2003, PPATK dapat pula menerima informasi dari pihak ketiga baik perorangan maupun entitas mengenai dugaan tindak pidana pencucian uang oleh sesuatu pihak.

PJK sebagai media pencucian uang, pesatnya kemajuan teknologi dan arus globalisasi di sektor perbankan membuat industri ini menjadi lahan yang empuk bagi para pelaku kejahatan pencucian uang. Pelaku kejahatan dapat memanfaatkan bank untuk kegiatan pencucian uang karena jasa dan produk perbankan memungkinkan terjadinya lalu lintas atau perpindahan dana dari satu bank ke bank atau lembaga keuangan lainnya sehingga asal usul uang tersebut sulit dilacak oleh aparat penegak hukum. Bahkan melalui sistem perbankan pelaku dalam waktu yang sangat cepat dapat memindahkan dana hasil kejahatan melampaui batas yurisdiksi negara, sehingga pelacakannya akan bertambah sulit apalagi kalau dana tersebut masuk ke dalam sistem perbankan yang negaranya menerapkan ketentuan rahasia bank yang sangat ketat.

Namun demikian, non-bank financial institution juga merupakan target yang tak kalah menarik bagi para pelaku pencucian uang. Kenyataan menunjukkan bahwa dalam beberapa tahun terakhir para pelaku pencucian uang telah membuat langkah terobosan dengan mempergunakan lembaga keuangan non bank sebagai sarana pencucian uang. Placement merupakan metode yang paling banyak digunakan oleh para pelaku dalam hubungan dengan lembaga keuangan non bank.

Perusahaan asuransi misalnya dapat dimanfaatkan melalui pembelian asuransi jiwa yang merupakan suatu tahapan melakukan placement dan sekaligus memuat unsur layering dan integration. Pengiriman uang melalui perusahaan pengiriman uang (money transfer), placement pada lembaga pembiayaan dan venture capital serta pelunasan pinjaman pada perusahaan sewa guna usaha (leasing) merupakan modusmodus yang dapat digunakan oleh para pelaku pencucian uang dengan menggunakan non-bank financial institution. 


\section{SIMPULAN}

Pencucian uang sebagai tindak pidana yang terorganisir biasanya disebut dengan sindikat atau jaringan. Tindakan pencucian uang mempunyai kerangka, model, modus operandi, instrumen, metode, tahapan dan pelaku tertentu dalam kegiatan kejahatan tersebut merupakan satu paket antara satu dengan lainnya. Ada dua media atau saran pencucian uang, yaitu pasar modal dan bank. Bank sebagai instrument pengembangan dan pertumbuhan ekonomi menjadi instrument handal bagi pelaku pencucian uang, sedangkan pencucian uang pada pasar modal sebagai instrument lebih mudah dengan cara mempergunakan tahapan integration dan dengan metode Buy and sell conversions dan Legitimate business conversions.

Pencucian uang pada suatu bank akan semakin terbuka apabila rahasia bank itu diberlakukan secara mutlak. Untuk itu diperlukan undang-undang khusus yang mengatur tentang bagaimana mendapatkan data keuangan bagi nasabah bank maupun pelaku pengguna jasa keuangan lainnya dalam kegiatan pasar modal. Disinilah Undang-Undang No.25 Tahun 2003 Tentang Tindak Pencucian Uang memberikan kewenangan penuh kepada lembaga Pusat Pelaporan dan Analisis Transaksi Keuangan (PPATK) untuk menghimpun informasi dan menganalisis seluruh data yang dicurigai sebagai hasil dari kejahatan tertentu yang disimpan atau diinvestasikan pada institusi keuangan untuk mengaburkan asalmuasal uang tersebut.

\section{DAFTAR PUSTAKA}

Gilmore, William C, Dirty Money:

The Evolution of Money

Laundering Countermeasures, Council of Europe Publishing, Belgium, 1999.

Henry Campbell Black, Black`s Law Dictionary, Sixth Edition, St. Paul Minn, West Publishing Co, 1991.

http:// www. suaramedia.com/ ekonomi-bisnis/ekonomi/ 6474-kasus-pencucian-uangterus-meningkat.html, diakses 1 Pebruari 2010.

http://www.ppatk.go.id/ laporan_ tahunan. php diakses 1 Pebruari 2010.

M. Irsan Nasarudin dan Indera Surya, Aspek Hukum Pasar Modal Indonesia, Prenada Media, Jakarta, 2004.

M. Irsan Nasarudin dan Indera Surya. Aspek Hukum Pasar Modal Indonesia. Kencana, Jakarta, 2004.

Marulak Pardede, Hukum Pidana Bank, Pustaka Sinar Harapan, Jakarta, 1995.

McDonnell Rick, Regional Implementation, Regional Conference on Combating Money Laundering and Terrorist Financing, Denpasar, 17 Desember 2002.

Muladi. Kapita Selekta Sistem Peradilan Pidana, Universitas Diponogoro, Semarang, 1995.

Munir Fuady, Bisnis Kotor (anatomi Kejahatan Kerah Putih), Citra Aditya Bakti, Bandung, 2004. 
Munir Fuady, Hukum Perbankan Indonesia, Cirtra Aditya Bakti, Bandung, 2001.

NHT. Siahaan, Pencucian Uang dan Kejahatan Perbankan, Sinar Harapan, Jakarta, 2005.

Sarah N. Welling, Smurfd, Money Laundring and the United Atate Criminal Federal Law. Dalam Brent Fisse, David Fraser and Graeme Coss, The Money Trail (Confiscation of proceed of Crime. Money Laundering and Cash Transaction Reporting), Sydney, The Law Book Company Limited, 1992.

Soerjono Sukanto, Pengantar Penelitian Hukum, Universitas Indonesia (UI-Press), Jakarta, 1986.

Sudarmadji. Essensi dan Cakupan UU Tentang Pencucian Uang di Indonesia, Makalah Seminar Nasional pada Sosialisasi Undang-Undang No. 15 Tahun 2002, Kerjasama Kajian Hukum dan Bisnis Fakultas Hukum Unsri dengan PT. Bank Pembangunan Daerah Sumatera Selatan pada 15 Juli 2002.

Undang-Undang No. 15 Tahun 2002 Jo. Undang-Undang No.15 Tahun 2003 tentang Tindak Pidana PencucianUang. 